pseudo-acid-fast bacilli resist for much shorter periods.

During the discussions on serotherapy it was stated that good results had been obtained by treatment with filtered broth cultures of tubercle bacilli as employed by Prof. Denis, of Louvain, with a new variety of tuberculin extracted from tubercle bacilli by means of a I per cent. solution of orthophosphoric acid introduced by Dr. Beraneck, of Neuchatel, and with the anti-toxic serum invented by Dr. Marmorek. The latter observer had made a medium of leuco-toxic serum, obtained by injecting goats with leucocytes of other animals, and spleen bouillon, and inoculated this from the very edge of young cultures of tubercle bacilli. These showed a rapid growth, and the products of their growth in this medium were injected into horses in repeated small doses; when these horses had been sufficiently immunised their blood was used as a source for the serum. This serum had given its best results in cases of surgical tuberculosis, i.e. diseases of joints and the like, but the effects in pulmonary tuberculosis were held to be such as to justify a more extended trial being given to this method.

In the subsection on therapeutics various methods of treatment were put forward, amongst others the intravenous injection of iodoform in suspension in a mixture of ether and liquid paraffin which had been tried with some success by Dr. Dewar, of Dunblane.

Several communications were made on the respiratory changes in the subjects of pulmonary tuberculosis, the general conclusion being that they in no wise differed from those in normal or slightly febrile individuals. A series of reports was made on the early diagnosis of pulmonary tuberculosis by radiography, cytoscopy, blood counts, and other methods. Dr. Theodore Williams pointed out that the time had not yet come for supplanting the ordinary methods of auscultation and percussion, an opinion strongly agreed to by Prof. Grancher and Dr. Turban, of Davos.

In the third section abundant evidence was given of the necessity of proper care being taken of children, especially to avoid infection, great stress being laid on the danger of their occupying the same room as a subject of pulmonary tuberculosis, and the absolute necessity for a properly supervised milk supply. In a general resolution of the congress it was decided to recommend the periodical Government inspection of all dairies, and that no public institution should make use of milk that had not either come from cows which had passed the tuberculin test or had been Pasteurised or boiled.

In the fourth section Dr. Newsholme directed attention to the diminution in the death rate from pulmonary tuberculosis which had followed the replacement of domestic by institutional relief.

A discussion on the relative merits of sanatorium and dispensary treatment resulted in the conclusion that each had its place, and that the educational factor must not be forgotten, since the diminution of tuberculosis depended more on prophylaxis than on individual treatment. The advantages of the French dispensaries over the out-patient departments of most English hospitals were that since one or more of these are situated in each district of Paris and other cities, patients have not far to come, and domiciliary visits could be made to encourage the carrying out of any precautions recommended. Owing to the distance from which patients come this was at present quite impossible to organise for London hospitals. Such a system had, however, been organised in connection with the dispensary attached to the Victoria Hospital in Edinburgh, and had been productive of most excellent results. It was in matters connected with hygiene and social factors generally that the most good resulted from the London congress, and it is to be hoped still more will follow the narration of the experience gained since that time. The real hope for the community as a whole would appear to lie in the protection of the individual, and more especially of the child, if Prof. Behring's views on latency and intestinal infection hold good, from infection rather than in the treatment of those already tuberculous, since even if treatment restore the latter to some degree of working capacity, and the average sanatorium result is put at five to seven years' prolongation of active life, they but serve as foci for fresh infection.

In addition to the actual scientific papers brought forward, perhaps the greatest and best work of the congress consisted in the private interchange of views between workers of different nationalities, and in the visits to various institutions, sanatoria, and hospitals in and around Paris.

The Pasteur Institute, the veterinary college at Alfort, the Boucicaut Hospital and the sanatoria at Bligny, Angicourt, and Ormesson were among those inspected by the greatest numbers.

At the concluding séance it was announced that the next congress would be held in America in three years' time.

\section{THE BRITISH ASSOCIATION IN SOUTH AFRICA.}

THE association party left Maritzburg early on Saturday morning, August 26, and proceeded through the upland districts to Colenso, where a halt of special interest had been arranged. Arriving at that now historic centre with some hours of daylight to spare, a visit was paid to the site of several battles and engagements connected with the attempts to relieve Ladysmith.

The next morning, August 27, the trains slowly steamed through one of the passes leading into Ladysmith, where evidence of the severity of the struggle of a few years ago was seen on every side in groups of graves and monuments. Ladysmith was left in the evening, and Majuba and Laing's Nek, with the scenes of struggles in the late war in northern Natal, were passed in the darkness. Daylight revealed Standerton in the Transvaal at hand, and Johannesburg was reached amid exclamations of wonder at the gigantic heaps of tailings from the gold workings which were passed during the last few miles of the journey.

Of the work done in Johannesburg in connection with the sections little need be said here, but the attendances were certainly remarkably good, and the discussions revealed a high average of capacity to discuss the various problems which were presented by the papers read. Prof. Darwin's own words at the close were felt to be fully deserved when he observed, in bringing the formal work to a close, that the meeting of the association in Cape Town and Johannesburg constituted one of the most remarkable and one of the most successful of the long series held in various centres in Great Britain, Ireland, and the colonies.

The more social functions connected with the visit to Johannesburg must be described as brilliant successes. These commenced with a reception by the mayor and town council at a conversazione held at the Wanderers' Club. His Excellency the High Commissioner, Lord Selborne, was present, and graciously received many of the more distinguished of the visitors and those who had been most prominent in preparing for the visit of the association in the different South African centres. 
On the following days visits were paid to various mines, both to the underground and surface workings, and to the native and Chinese compounds; and courteous guides explained the various gold extraction processes. At one of the mines some thousands of natives delighted the visitors with a Kafir dance to the accompaniment of music on native pianos and drums.

A lecture by Prof. Ayrton on "The Distribution of Power," which had involved some weeks of preparation of elaborate machinery, was greatly appreciated, though many heard with wonder of his disparagement of the Victoria Falls as possible sources of power in the future.

A garden party at Sunnyside to which an invitation was given by Lord Selborne was very largely attended. Perhaps the great event of the Johannesburg visit was the occasion of Prof. Darwin's presidential address, which consisted of a résumé of the main features of the Cape Town section and the delivery of the second half of his official paper.

Opportunity was taken by Lord Selborne and $\mathrm{Mr}$. George Goch, the Mayor of Johannesburg, to tender official welcomes to the association, to which the president replied in one of the graceful and fitting addresses which have constituted so noteworthy a feature of the visit.

Thursday, August 3I, was taken up with a visit to Pretoria as the main attraction, with the addition of visits to the Modderfontein Dynamite Factory and the Premier Diamond Mine.

At Pretoria the whole party was entertained at luncheon at some of the principal hotels, and in the afternoon Sir Arthur Lawley, Lieutenant-Governor of the Transvaal, held a reception at the museum. The president and some of the visitors stayed overnight in Pretoria, where Mr. A. E. Shipley gave a lecture on "Fly-borne Diseases." The same evening Prof. J. O. Arnold lectured in Johannesburg on "Steel as an Igneous Rock."

During the concluding day of the Johannesburg visit, the general committee meeting and the annual meeting of members were held, when Dr. Ray Lankester was elected president of the association for the ensuing year, and the officers and council were re-elected with slight changes only in the personnel of the latter.

As many of the papers read at the various sections had proved of deep South African interest, it was heard with pleasire that local arrangements were being made to publish the same in a separate volume subject to the consent of the authors being obtained.

From Johannesburg and Pretoria several treks of special interest to geologists and others were arranged, and among these were journeys across country to Mafcking, which necessitated omitting the visits to Bloemfontein and Kimberley, but evidently resulted in compensation of quite another kind to those who braved the inconveniences and hardships of the journey.

Prior to leaving Johannesburg Prof. Darwin announced that some of his fellow-members desired to establish a permanent link between the association and South Africa, and it had been proposed that a subscription should be raised for a medal to be given annually to a South African student in commemoration of the visit of the British Association.

The journey to Bloemfontein did not afford much opportunity of seeing the country until early morning, when several scenes of war interest were passed. The arrival in Bloemfontein on Saturday, September 2 , was followed by a public welcome by the mayor and town councillors and the local Philosophical Society in the Town Hall. The function was NO. 1876 , VOL. 72 ] numerously attended, and the addresses were giver and received with equal cordiality. During the morn. ing the various public buildings were visited, and in the afternoon a reception and garden party were held.

In the absence through illness of Sir H. J. GooldAdams, the Lieutenant-Governor, his place was taken by the Acting Chief Justice, Mr. Justice Fawkes, and Mrs. Fawkes, who graciously received the visitors. The trees and bush of the grounds afforded welcome shade, and all the accessories of the occasion were such as conduced to the comfort and pleasure of all present. In the evening $\mathrm{Mr}$. A. R. Hinks lectured on "The Milky Way and the Clouds of Magellan."

On September 3 a visit was paid by train to the Government Experimental Farm at Tweespruit, a halt being made en route at Sannah's Post with its lamentable memories. In the course of the day a trek party left for Kimberley by way of Abraham's Kraal and Paardeberg, the scene of General Cronje's capture.

On the morning of Monday, September 4, the main party left by train and proceeded by Nowal's Pont, Naauwpoort and De Aar to Kimberley, which was reached early the next morning. The programme of entertainments for the next two days was very full. Naturally the diamond mines were the centres of greatest interest, and ample provision had been made for visits underground, to the pulsator, compounds, and surface works generally. Parties were made up of numbers sufficiently limited to admit of adequate explanation of the various processes being given, an arrangement which was much approved.

On the afternoon of the first day, September 5, the mayor and mayoress, Mr. J. D. and Mrs. 'Tyson, held a garden party in the Public Gardens, which afforded a much coveted opportunity for introductions of citizens to visitors. In the evening Sir Wm. Crookes gave his lecture on "Diamonds" in the Town Hall. Elaborate preparations had been made for the interesting experiments by which the lecture was illustrated, and these passed off most successfully. So numerous were the applications to attend the lecture that Sir William kindly repeated it the following afternoon.

On Wednesday morning, September 6, most of the visitors were taken by special train to the Du Toit's Pan and Wesselton mines, and the compound life of the natives was more minutely examined. The open workings at Wesselton enabled a more perfect idea to be formed of the methods which obtained in the older mines at the beginning of operations. During the day Alexandersfontein and Kenilworth attracted many visitors, and in the evening Prof. J. B. Porter, of McGill University, gave a lecture entitled "The Bearing of Engineering on Mining."

At mid-day on Thursday, September 7 , the special trains for Bulawayo commenced to leave, and a journey which lasted until Saturday morning, September 9, introduced the travellers to many interesting scenes, many of which were of a type entirely different from any hitherto experienced. The richly wooded districts of British Bechuanaland called for frequent use of the camera, and not a few curios were purchased from the natives.

On arrival at Bulawayo, where the accommodation was limited, many of the party had to sleep in the train, a proceeding which, however, was hardly regarded as an inconvenience.

The library, which had been turned into a reception room for the occasion, brought a numerous company together, and the post-office counter was thronged for a considerable period owing to the great demand for the new Victoria Falls stamps just issued in 
different values. The revenue had no small gains from the sales, hundreds of sets being bought up and cancelled without being used.

In the course of the morning of September 9 Prof. Darwin opened the recently acquired museum, which on being entered was found to contain a local collection of great scientific interest. Many of the visitors expressed their regret that time was not available for a more minute study than was possible on this occasion. The afternoon was taken up by a visit to Government House, the site of Lobengula's kraal, where, in the absence of the Administrator, a reception was held by the Treasurer, Mr. Newton. Lobengula's tree of justice was a centre which all sought.

In the evening Mr. D. Randall Maclver gave a lecture-report on the "Rhodesian Ruins " which attracted a numerous audience, it having been whispered abroad that his conclusions ran counter to the theories of great antiquity which have hitherto generally held the field. Mr. Mactver's address was lengthy, and dealt chiefly with one class of evidence. Although the last word has not been said upon the subject, Mr. MacIver has certainly thrown new light upon it.

The Matopos and World's View, with the tomb of Cecil Rhodes and the Shangani monument, which called for two special trains to convey the visitors, seem to have surpassed all preconceptions, and the magnificence of the surrounding views and the quiet dignity of the last resting-place of Rhodes seem to have created the same feeling in the breast of nearly everyone present, a desire to contemplate the whole scene in the silence and solitude impossible on such an occasion. A brief religious service was conducted by the Rev. Mr. Bevan at the side of the tomb.

On Monday morning, September II, five special trains left for Victoria Falls, and the journey through the teak forests seemed a fitting prelude to the solemn grandeur of the scenes to be viewed on the morrow.

Only some thirty hours were allotted to the falls visit, but such were the arrangements made by Sir Charles Metcalfe that the main features, both of the falls, the ravine below, and the river above, could be compassed by the energetic sightseer in the time.

The first business of the day was the opening of the new bridge by Prof. Darwin, after which Palm Kloof, Livingstone Island, the Rain Forest, and many other points of vantage and interest were visited. Not a few also enjoyed a moonlight visit to the falls, the moon fortunately being full. The next morning canoes were requisitioned for trips up the lovely island-dotted river, and the "hippos" were obliging enough to put in an appearance for the occasion. Soon after noon the special trains commenced the return trip to Bulawayo, the first stage on the journey home.

At Bulawayo the trip, which, save for a few special excursions, had been of a homogeneous character, was brought to an end. The party was here divided into two sections, the one preferring the voyage home by way of Cape Town, the other via Beira and the east coast. The latter route proved to possess the greater attractiveness, judging by the numbers who elected to return that way, which was not surprising when an opportunity of making the round journey in such circumstances was considered.

Of the visit as a whole it only remains to add that it has been a success beyond the most sanguine dreams of its promoters. The hospitality throughout has been generous to the extent of lavishness, the labour of the various local committees has been as wisely exercised as it has been unremittingly pursued, and the only regret seems to have been that the time allotted to each town was necessarily so short.

$$
\text { No. } 1876 \text {, vOL. } 72]
$$

That the true interests of science both in the mother country and in the colonies have been advanced by this unique meeting of the association cannot be doubted, and the results will continue to be seen in many directions after many days.

\section{THE BRITISH SCIENCE GUILD.}

$\mathrm{THE}$ inaugural meeting of the British Science Guild will be held at the Mansion House on Monday, October 30; and the Lord Mayor, who has consented to preside, will take the chair at 4.15 p.m. The guild appeals to the people of Britain within and beyond the seas, and its chief object is to bring home to all classes the necessity of making the scientific spirit a national characteristic which shall inspire progress and determine the policy in affairs of all kinds. The organisation is associated with no political party, and its membership is open to all British subjects, whether men or women.

At the inaugural meeting of the guild, on October 30 , the following officers will be proposed :-

President: the Right Hon. R. B. Haldane, K.C., M.P.; vice-presidents : the Right Hon. the Lord Mayor of London, Sir Lawrence Alma-Tadema, R.A., O.M., the Right Hon. Lord Balcarres, M.P., the Right Hon. the Earl of Berkeley, Sir William Broadbent, Bart., K.C.V.O., F.R.S., Sir Walter Buller, K.C.M.G., F.R.S., Sir J. Burdon-Sanderson, Bart., F.R.S., Major-General Sir Owen Tudor Burne, G.C.I.E., K.C.S.I., Sir William Church, Bart., Sir George Sydenham Clarke, K.C.M.G., F.R.S., Sir John Colomb, K.C.M.G., M.P., the Right Hon. the Earl of Donoughmore, the Right Hon. Earl Egerton of Tatton, Sir John Eliot, K.C.I.E., F.R.S., Sir Michael Foster, K.C.B., O.M., M.P., F.R.S., the Right Hon. Sir Edward Fry, F.R.S., Sir Archibald Geikie, F.R.S., Mr. F. Du Cane Godman, F.R.S., the Right Hon. Sir John Gorst, K.C., M.P., F.R.S., the Right Hon. Lord Haliburton, G.C.B., Sir Joseph Hooker, G.C.S.I., F.R.S., the Right Hon. Viscount Knutsford, G.C.M.G., Prof. Ray Lankester, F.R.S., Dr. J. Larmor, F.R.S., the Right Hon. Lord Lister, F.R.S., Sir Charles McLaren, Bart., K.C. M.P., the Right Hon. Sir Horace Plunkett, K.C.V.O., F.R.S., Mr. E. Robertson, K.C., M.P., the Right Hon. Lord Tennyson, P.C., G.C.M.G., His Grace the Duke of Wellington, K.G., G.C.V.O.; chairman of committees : Sir Norman Lockyer, K.C.B., F.R.S. ; vice-chairmen : Sir William Abney, K.C.B., F.R.S., Sir Lauder Brunton, F.R.S., the Hon. Sir John Cockburn, K.C.M.G., Sir Gilbert Parker, M.P.; trustees: the Right Hon. Lord Strathcona and Mount Royal, G.C.M.G., Sir Henry Roscoe, F.R.S.; hon. treasurer: the Right Hon. Lord Avebury, F.R.S.; hon. assist. treasurer: Lady Lockyer, I6 Penywern Road, S.W.; hon secretary: Mr. C. Cuthbertson.

A large general committee, which will include the names of the present organising committee, will also be proposed for election.

Since the first meeting, held at the rooms of the Royal Society in April, IgO4, the labours of the organising committee have been directed to securing the help of representatives of all sides of the nation's activities to secure the objects of the guild, which are

(I) To bring together as members of the guild all those throughout the Empire interested in science and scientific method, in order, by joint action, to convince the people, by means of publications and meetings, of the necessity of applying the methods of science to all branches of human endeavour, and thus to further the progress and increase the welfare of the Empire.

(2) To bring before the Government the scientific aspects of all matters affecting the national welfare.

(3) To promote and extend the application of scientific principles to industrial and general purposes. 